Chkhatarashvili Guram

\title{
Final upper Paleolithic assemblages from South Caucasus (Dzudzuana Cave)
}

Georgia was distinguished by advantageous natural-geographic location, from the ancient times, with diverse and contributing climate conditions. It seems that this fact determined the wide settlement of a man here, as evidenced by number of different kinds of habitations of Stone Age and of other eras. The results of archeological researches of the second half of the last century show that Georgia is the ancient place where the settlement of man on the continent of Europe was held. Scientists suppose that ancient man entered Eastern Georgia (Dmanisi) from Africa through so-called Levantin Corridor and Dmanisi region became the ancient distribution hub of a man in Eurasia. In addition, Georgia, in particular, its western part is rich with upper paleolithic sites. One of our purpose is to show final Upper Paleolithic culture of South Caucasus based on Dzuduzuana cave materials.

Dzudzuana cave site, in the Imereti region (Chiatura municipality), is situated on the right bank of the Nekrissi river, a tributary of the Kvirila river, which drains most of Western Georgia (Figure 1-2). The cave is a large, elongated hall, emerging as a tunnel from which a small creek flows. The wide opening of the cave (22 meters) and high ceiling (ca. $15 \mathrm{~m}$ ). At first time archaeological excavations in Dzdudzuana cave have been conducted in 1966-1975 was directed by D. Tushabramishvili (Meshveliani et al., 1999) and covered area of $40 \mathrm{~m}^{2}$ near the cave entrance which was excavated down to bedrock. The excavations were carried out in units $0.1 \mathrm{~m}$ deep in $1 \mathrm{~m}^{2}$ squares and artifacts were recovered by hand, without wet-sieving. The stratification was subdivided into two major units Layer I - the Upper Eneolithic and Layer II - the Upper Paleolithic deposits, which he subdivided into eight layers (Liubin; 1989). Faunal remains from these excavations were identified by Bendukidze (Bendukidze; 1978). The bone assemblage was found to include Caucasian tur (Capra caucasica) and the extinct steppe bison (Bison priscus), as well as red deer (Cervus elaphus), aurochs (Bos primigenius), wild boar (Sus scrofa), wild horse
(Equus caballus), wolf (Canis lupus) and pine marten (Martes martes) (Bar-Oz et al., 2008: 132).

In 1989, T. Meshveliani subsequently sought to revise the Georgian Upper Paleolithic sequence based on reexaminations of collections from most of the Upper Paleolithic sites in the regional sequence. Signiucantly, his study tried to incorporate data obtained through geological, palynological, and paleontological investigations (Meshveiani, 1989; Meshveliani et al, 2004: 132).

Since 1996 in Dzuduzana cave took place Georgian-USA-Israeli international joint archaeological excavations (head of expedition T. Meshveliani). During this were excavated two areas: the first, an extension of Tushabramishvili's excavations near the entrance of the cave (squares F-I 9-7 and J-K 12-11), which was called hereafter the "lower area". The second an "upper area" comprising squares G-H 24-21, 19-15 (figure 3). The total excavated surface was $24 \mathrm{~m}^{2}$. The basic units of excavation were $50 \mathrm{~mm}$ thick quadrants of $0.5 \times 0.5 \mathrm{~m}$, within a $1 \times 1 \mathrm{~m}$ grid (Bar-Yosef et al., 2011: 333). All excavated sediments were wet sieved through $2 \mathrm{~mm}$ mesh and the dried sediments were hand-picked for the small bones and lithics. All bones were saved and processed according to their spatial and stratigraphic locations. The total depth of the Upper Palaeolithic deposits is about $3.5 \mathrm{~m}$, divided into four major stratigraphic units. B unit is belong to final Upper Paleolithic period and dates back between 16.5 and $13.2 \mathrm{Ka}$ cal BP. Total amounts of studied artifacts are 26219. (Table I). Cores are different size and forms. There are many blades and bladelets in this unit; most of them are retouched and backed. We have noted tools too. It should be noted high percentages of end scrapers which is outnumber the burins (Table II). End scrapers are different sizes and forms, many of them made on flakes and have „thumbnail" variety; The dominant microlithic types are microgravette and elongated straight-backed bladelets. The former are generally blades or bladelets, 11-16 $\mathrm{mm}$ wide, shaped by bipolar retouch. The bone artifacts only eight items (Table III, Figure 4). One of them is a decorated. 
Dzudzuana cave rich in faunal remains too. Bison (Bison priscus), aurochs (Bos primogenius) and Caucasian tur (Capra caucasica) are the most common taxa in all occupation levels. Other ungulate species are represented in small frequencies and include primarily red deer (Cervus elaphus) (Bar-Oz et al, 2008: 343). In layer B, the ratios of Bos/Bison are similar to those of Caucasian tur, both in the lower and upper part of the cave. Other species, represented in small frequencies in all occupational layers at the site, include red deer, wild horse, wild boar, hare (Lepus europeus) and carnivores (brown bear (Ursus arctos), wolf, fox (vulpes vulpes) and beech (marten). Their frequencies do not change over time.

The age structure of the major hunted species (Caucasian goat and steppe bison) was analyzed on the basis of tooth wear. Specialists were followed by Stiner (Stiner, 1994) in distinguishing three broad age classes (juvenile, prime adult and old adult) using the eruption and tooth wear patterns of deciduous lower fourth premolar (dP4) and lower third molar (M3) (Bar-Oz, et al, 2004: 48).

Although large mammals are rather rough indicators of palaeoecological conditions, the presence of Caucasian tur is indicative of cool the Alpine conditions, presence of steppe bison and equids indicate open habitats along the Caucasian steppe, and that of aurochs and red deer, more temperate and forest conditions. It could be that the differences in species abundance observed between the layers reflect differences in the season of site occupation. Caucasian tur lives along steep rocky slopes at elevations between 800-2400 m and it follows a dramatic seasonal migration that can cover a vertical distance of more than $1500 \mathrm{~m}$. In the early spring, the herd climbs high into the mountains, descending into the upper part of the boreal forest in the later autumn (Heptner et al., 1989). The steppe bison is now extinct from the southern parts of the Caucasus, but it used to inhabit both woodland and grassland landscapes. In the late autumn this species would descend to the open steppe and grasslands at the base of the foothills in search of better feeding grounds, and in the early spring, they climbed to the woodland in the mountainous areas (Heptner et al., 1989; Bar-Oz et al, 2008; 135).

During the palynological analysis revealed that the palynological spectra (five samples) from Unit B demonstrate a major change from bottom to the top. The lower part is characterised by large amounts of rhododendron (Rhododendron caucasica) pollen and other highland elements that suggest the presence of an alpine belt in the vicinity of the cave. This "colder conditions event" was prior to the Younger Dryas, but additional dates are needed for establishing a firmer climatic correlations. The change from the cold conditions 0 an increase in humidity is indicated by the presence of a highland dark coniferous forest of spruce, fir and pine with rare occurrences of beech (Bar-Yosef et al, 2011: 337).

Although by specialists conducted systematic flotation, no prehistoric plant remains were recovered. However, during the course of pollen analysis (by palynologic E. Kvavadze) numerous non-pollen polymorphs were discovered. Among these were unique finds of wild flax fibres, including spun and dyed ones. Fibres were recovered from all archaeological layers, but in B layers, it was 48 (Table III) (only three of which were colored, one black and two turquoises) (Kvavadze et al, 2009: 359). Zoological fossils include microscopic remains of mites (Acari) and hair of abdominal segments of the larva of beetle (Coleoptera, family Dermistidae). There are also tur hairs, spun and dyed (in grey and green).

The remains of fur, micro-remains of skin beetles and moth can be interpreted as evidence for working hide and flax. The samples with the highest content of flax also contained spores of the fungus Chaetomium, which usually grows on clothes and textiles and destroys them (Bar-Yosef et al, 2011: 344).

The best match for Dzudzuana Unit B is Sakajia Cave recently yielded a radiocarbon date on a bovid bone of $11700 \pm 80$ BP (calibrated $13830 \pm 148$, OxA-7853) (Nioradze, Otte; 2000), Apiancha Cave (two radiocarbon readings of c. 17.9-17.6 ka cal BP) (Korkia 1998), Satsurblia (Area A, Layers A/lla and A/llb: 17.9-16.2 ka cal. BP) (Pinhasi et al, 2014) and others sites.

As we can see, final upper Paleolithic culture in Dzuduzana cave are well presented.

1. Stone assemblage is rich retouch and backed blade and bladelets, microgravette's and geometric microliths;

2. Palynological investigations indicate presence of a highland dark coniferous forest of spruce, fir and pine with rare occurrences of beech;

3. Faunal remains show us that Bison, Aurochs and Caucasian tur is the most common taxa in this period. Naturally, this fact is indicating that these species were high used by primeval men. 
Table I. Debitage of Unit B

\begin{tabular}{|r|r|l|l|}
\hline & & $\mathbf{N}$ & $\%$ \\
\hline 1. & Pr. flake & 1.446 & 5.51 \\
\hline 2. & Pr. blade & 294 & 1.12 \\
\hline 3. & Pr. Other & 87 & 0.33 \\
\hline 4. & Blade & 2.032 & 7.75 \\
\hline 5. & Bladelets & 2.244 & 8.55 \\
\hline 6. & Clakes & 5.379 & 20.51 \\
\hline 7. & Cores & 354 & 1.35 \\
\hline 8. & Nodule & 64 & 0.24 \\
\hline 9. & Chunks & 808 & 3.08 \\
\hline 10. & Chips & 12.368 & 47.17 \\
\hline 11. & Others & 1143 & 4.3 \\
\hline & TOTAL: & 26.219 & \\
\hline
\end{tabular}

Table II. Tool types of Unit B

\begin{tabular}{|r|r|l|l|}
\hline \multicolumn{2}{|r|}{} & N & $\%$ \\
\hline 1. & Backed blade & 13 & 1.3 \\
\hline 2. & Backed bladelet & 99 & 1.9 \\
\hline 3. & Retouched blade & 42 & 3.2 \\
\hline 4. & Retouched bladelet & 79 & 4.2 \\
\hline 5. & Retouched fragment & 13 & 7.9 \\
\hline 6. & Endscraper & 232 & 1.3 \\
\hline 7. & Burins & 47 & 32.3 \\
\hline 8. & MicroGravettes & 66 & 4.7 \\
\hline 9. & Geometric microlithics & 16 & 6.6 \\
\hline 10. & Others & 358 & 1.6 \\
\hline 11. & TOTAL: & 997 & 35.9 \\
\hline & & \\
\hline
\end{tabular}

Table III. Distribution of fibres in pollen samples from Unit $B$

\begin{tabular}{|c|c|c|c|}
\hline Unit & Sq. & Depth, cm & Flax fibers \\
\hline B & H-19 & 350 & 10 \\
\hline B & H-19 & 385 & 5 \\
\hline B & H-19 & 395 & 11 \\
\hline B & H-19 & 410 & 6 \\
\hline B & H-19 & 415 & 6 \\
\hline B & H-19 & 430 & 3 \\
\hline B & H-19 & 435 & 7 \\
\hline & & & $\mathbf{4 8}$ \\
\hline
\end{tabular}




\section{REFERENCES}

Bendukidze O. 1978. Mammal Fauna of the Dzudzuana Paleolithic Settlement in Western Georgia. Cbornik Pechereh Gruzia (The Caves of Georgia) 7: 72-79

Bar-Oz G., Adler A., Vekua A., Meshveliani T., Tushabramishvili N., Belfer-Cohen A., BarYosef O., faunal exploitation patterns along the south slopes of the Caucasus during the late Middle and Early Upper Paleolith, 9-th ICAZ Conference, Durham, 2004, colonisation, migration and marginal areas (ed. M. Mondini, S. Munoz, S. Wickler), p.p. 46-54

Bar-Oz G., Belfer-Cohen A., Meshveliani T., Jakeli N., Bar-Yosef O. 2008. Taphonomy andzooarchaeology of the Upper Palaeolithic cave of Dzudzuana, Republic of Georgia. International Journal of Osteoarchaeology 18: 131-51.

Bar-Yosef O., Belfer-Cohen A., Mesheviliani T., Jakeli N., Bar-Oz G., Elisabetta Boaretto E., Goldberg P., Kvavadze E., Matskevich Z., Dzudzuana: an Upper Palaeolithic cave site in the Caucasus foothills (Georgia), ANTIQUITY 85 (2011): 331-349

Heptner V.G., Nasimovich A.A., Bannikov A.G. 1989. Mammals of the Soviet Union, Vol. 1: Ungulates. E.J. Brill: Leiden.

Korkia L.D. 1998. Upper Palaeolithic culture of the north-eastern Black Sea littoral of Georgi, Tblisi: Metsniereba (in Georgian with Russian summary).

Kvavadze E., Bar-Yosef O., Belfer-Cohen A., Boaretto E., Jakeli N., Matskevich Z., Meshveliani T. 2009. 30 000-year-old wild flax fibers. Science 325(5946): 1359.
Liubin V.P. 1989. Paleolit Kavkaza (The Paleolithic of the Caucasus). In Paleolit Kavkaza i Severnoj Azii, Boriskovsky PI (ed.). Nauka: Moscow; 9-142.

Meshveliani T. 1989. About the early stages of the Upper Palaeolithic cultures in western Georgia. Sakartvelos sakhelmtsipo muzeumis moambe 90(B): 13-31

Meshveliani T., Bar-Yosef O., Belfer-Cohen A., Djakeli N., Kraus A., Lordkipanidze D., Tvalchrelidze M., Vekua A. 1999. Excavations at Dzudzuana Cave, Western Georgia (1996-1998): preliminary results. Pre'histoire Europeenne 15: 79-86.

Meshveliani T., Bar-Yosef O., Belfer-Cohen A. 2004. The Upper Palaeolithic in western Georgia, in P. J. Brantingham, S.L. Kuhn \& K.W. Kerry

(ed.) The Early Upper Paleolithic beyond western Europe: 129-43. Berkeley (CA): University of California Press.

Nioradze M.G., Otte M.2000. Pal'eolithique sup'erieur de Georgie. L'Anthropologie 104: 265-300.

Pinhasi R., Meshveliani T., Matskevich Z., Bar-Oz G., Weissbrod L., Miller C.E., Wilkinson K., Lordkipanidze D., Jakeli N., Kvavadze E., Thomas F.G., Higham T F.G, Belfer-Cohen A. 2014. Satsurblia: New Insights of Human Response and Survival across the Last Glacial Maximum in the Southern Caucasus October 2014 | Volume 9 | Issue 10 | e111271, www.plosone.org

Stiner M.C. 1994. Honor among Thieves: a Zooarchaeological Study of Neanderthal Ecology. Princeton University Press: Princeton. 
Chkhatarashvili G.

\section{Final Upper Palaeolithic assamblages from South Caucasus (Dzudzuana Cave)}

In this paper we present Final upper Paleolithic assemblages from South Caucasus (Dzudzuana Cave) . Dzudzuana cave site, in the Imereti region (Chiatura municipality), is situated on the right bank of the Nekrissi river, a tributary of the Kvirila river, which drains most of Wcstern Georgia. The cave is a large, elongated hall, emerging as a tunnel from which a small creek flows. The wide opening of the cave (22 meters) and high ceiling (ca. $15 \mathrm{~m}$ ). Excavations in Dzdudzuana cave have been conducted in two campaigns: The first in 1966-1975, was directed by D. Tushabramishvili. There was discovered two layers: the Eneolithic and the Upper Palaeolithic deposits. A second campaign took place in 1996-2008 (head of expedition T. Meshveliani). The basic units of excavation were $50 \mathrm{~mm}$ thick quadrants of $0.5 \times 0.5 \mathrm{~m}$, within a $1 \times 1 \mathrm{~m}$ grid. The excavated deposits were wet-sieved, dried and later handpicked in order to retrieve the smallest archaeological components (lithics, bones, etc.).

Final upper Paleolithic period (B layer) in Dzudzuana cave dates back between 16.5-13.2 Ka cal BP. This layer comprises an assemblage characterised by the presence of microgravettes and backed and retouched bladelets. The local character of these assemblages is marked by the consistently high percentages of endscrapers, which always outnumber the burins, through all the archaeological occupations on site. There are elongated blades, c. $80 \mathrm{~mm}$ long, but most of the debitage comprises flakes, small blades, bladelets and debris. There are no obsidian cores and only c. 50 debitage artefacts.

Dzudzuana cave rich in faunal remains too. As we can see, Bison (Bison priscus), aurochs (Bos primogenius) and Caucasian tur (Capra caucasica) are the most common taxa in all occupation levels. Other ungulate species are represented in small frequencies and include primarily red deer (Cervus elaphus). The palynological spectra (five samples) from Unit B demonstrate a major change from bottom to the top. The lower part is characterised by large amounts of rhododendron (Rhododendron caucasica) pollen and other highland elements that suggest the presence of an alpine belt in the vicinity of the cave.

Although, during the course of pollen analysis (by palynologist E. Kvavadze) numerous non-pollen polymorphs were discovered. Among these were unique finds of wild flax fibres, including spun and dyed ones. Fibres were recovered from all archaeological layers, but in B layers which is interesting for us, it was 48.

Чхатарашвілі Г.

\section{Фінальнопалеолітичні комплекси Південного Кавказу (печера Дзудзуана)}

Печерна стоянка Дзудзуана (регіон Імеретія, Чіатурський муніципалітет) розташована на правому березі річки Некрісі, притоки Квіріли, яка протікає по більшій частині Західної Грузії. Печера велика, наче видовжений хол, у вигляді тунелю, з якого витікає невеликий струмок. Печера досить широка (22 м) та має значну висоту (близько 15 м). Дослідження в печері були проведені в два етапи. Перший - 1966-1975 рр., під керівництвом Д. Тушабрамішвілі, під час якого було знайдено два шари: енеолітичний та рештки верхньопалеолітичного. Другий етап відбувався в 1996 - 2008 рр., під керівництвом Т. Мешвеліані. Основною розкопок була сітка квадратів $1 \times 1$ м, розділена на менші квадрати 0,5×0,5м., потужністю 50 мм. Знайдені рештки були промиті, висушені на відсортовані (камінь, кістка тощо).

Фінал верхнього палеоліту (шар В) в печері Дзудзуана датується 16500 - 13200 тис. р. тому. Шар представлений комплексом з характерними для мікрогравету пластинками з притупленим краєм. Локальною особливістю таких комплексів $\epsilon$ стабільно високий відсоток скребків, які впродовж всього періоду існування стоянки кількісно переважають над різцями. Також були знайдені продовгуваті пластини, близько 80 мм завдовжки, проте більшість відходів виробництва становили відщепи, дрібні пластини, пластинки та лусочки. Обсидіанових нуклеусів знайдено не було, проте знайдено близько 50 уламків артефактів 3 нього.

Фауністичні рештки також представлені у печері. Найбільш поширеними були рештки бізона, зубра та кавказького бика. Інші ж копитні, в тому числі і благородний олень, представлені лише невеликими уламками. Палінологічні дослідження шару В відображають основні зміни. На основі аналізу п'яти зразків на нижньому рівні було виявлено високу концентрацію пилку рододендрону та інших високогірних елементів, притаманних альпійському клімату. Хоча, під час аналізу, проведеного Е. Киявадзе, було виявлено чисельні не пилкові поліморфи, в тому числі унікальні висушені та пофарбовані волокна дикого льону. Волокна були присутні на всіх шарах пам'ятки. В шарі B, зокрема, їх було виявлено 48. 


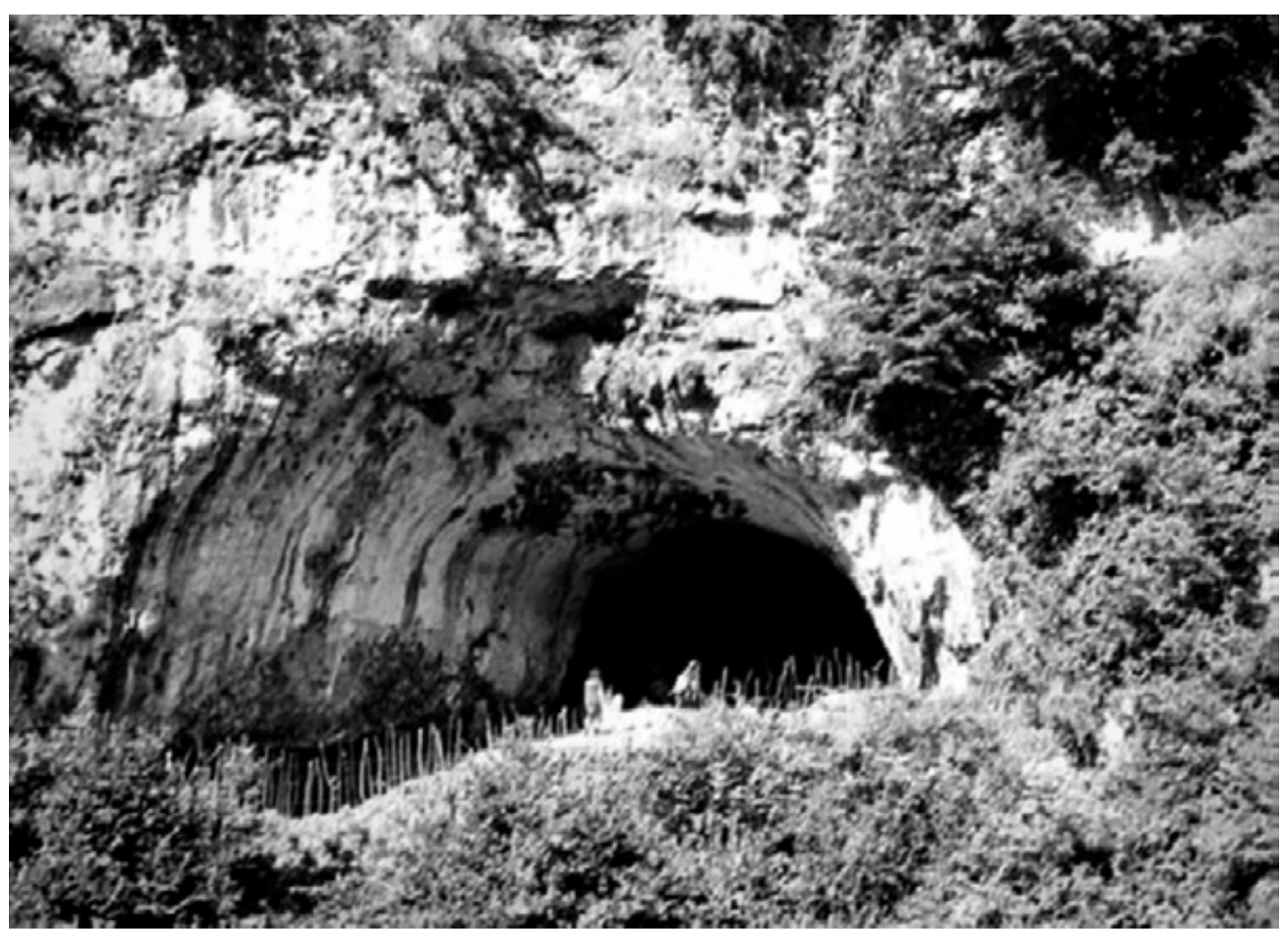

Fig. 1. Dzudzuana cave.

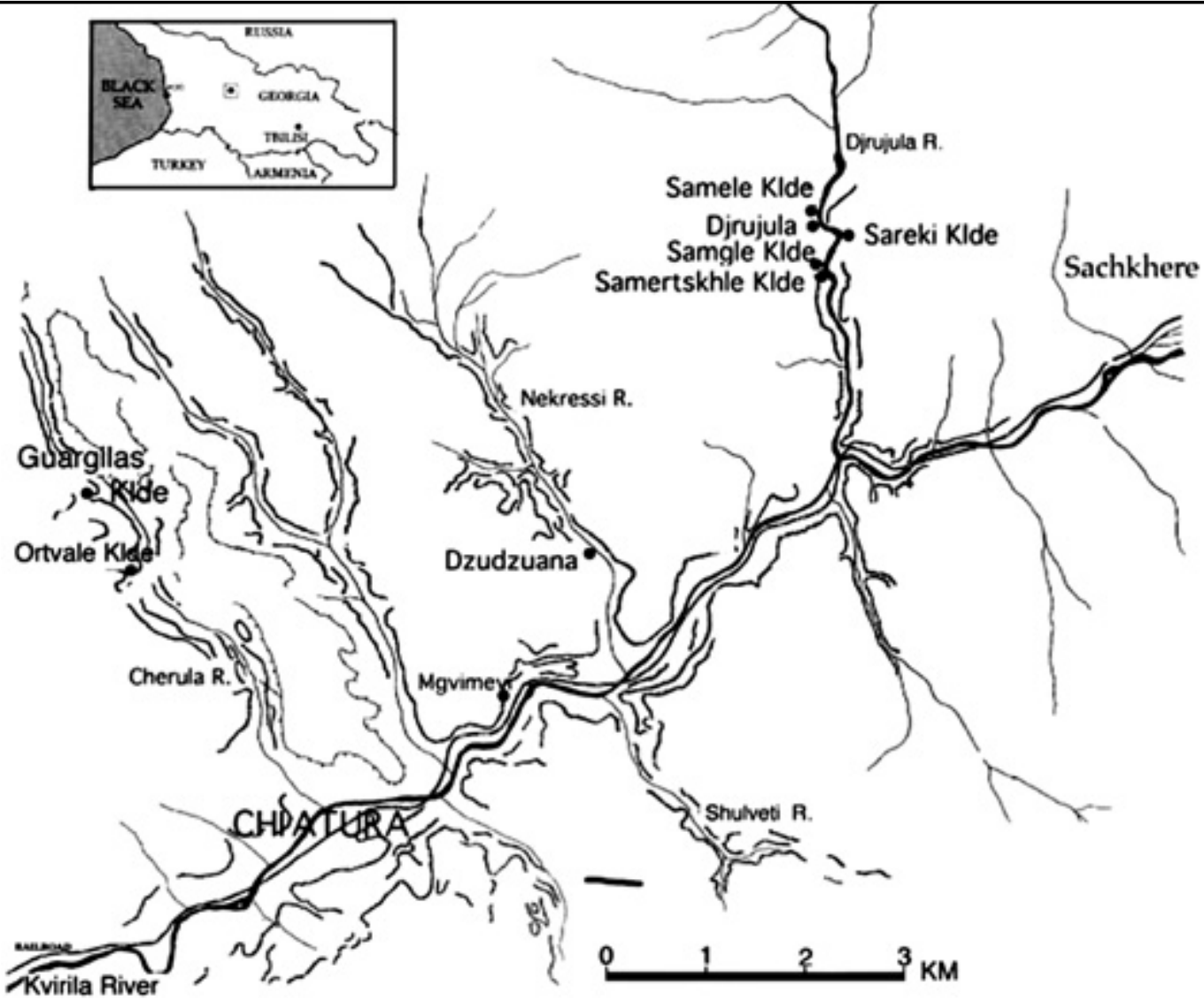

Fig. 2. Map showing the site. 


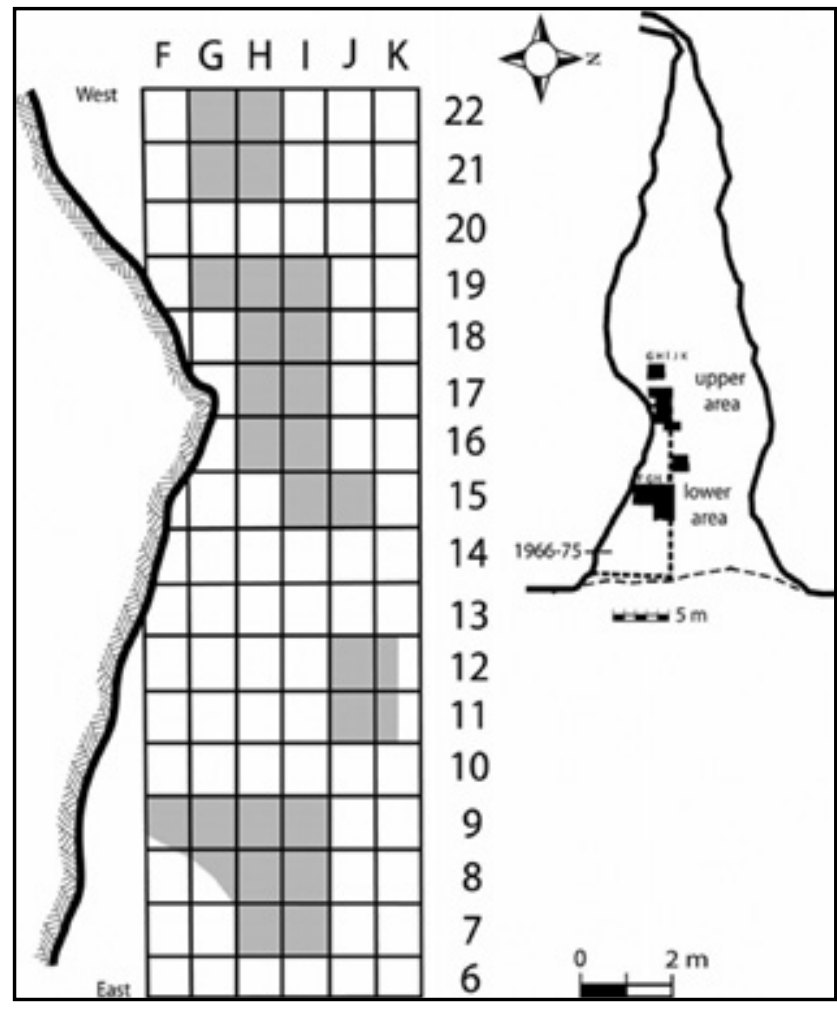

Fig. 3. Plan of Dzudzuana cave and excavated areas (Bar-Yosef et al, 334).
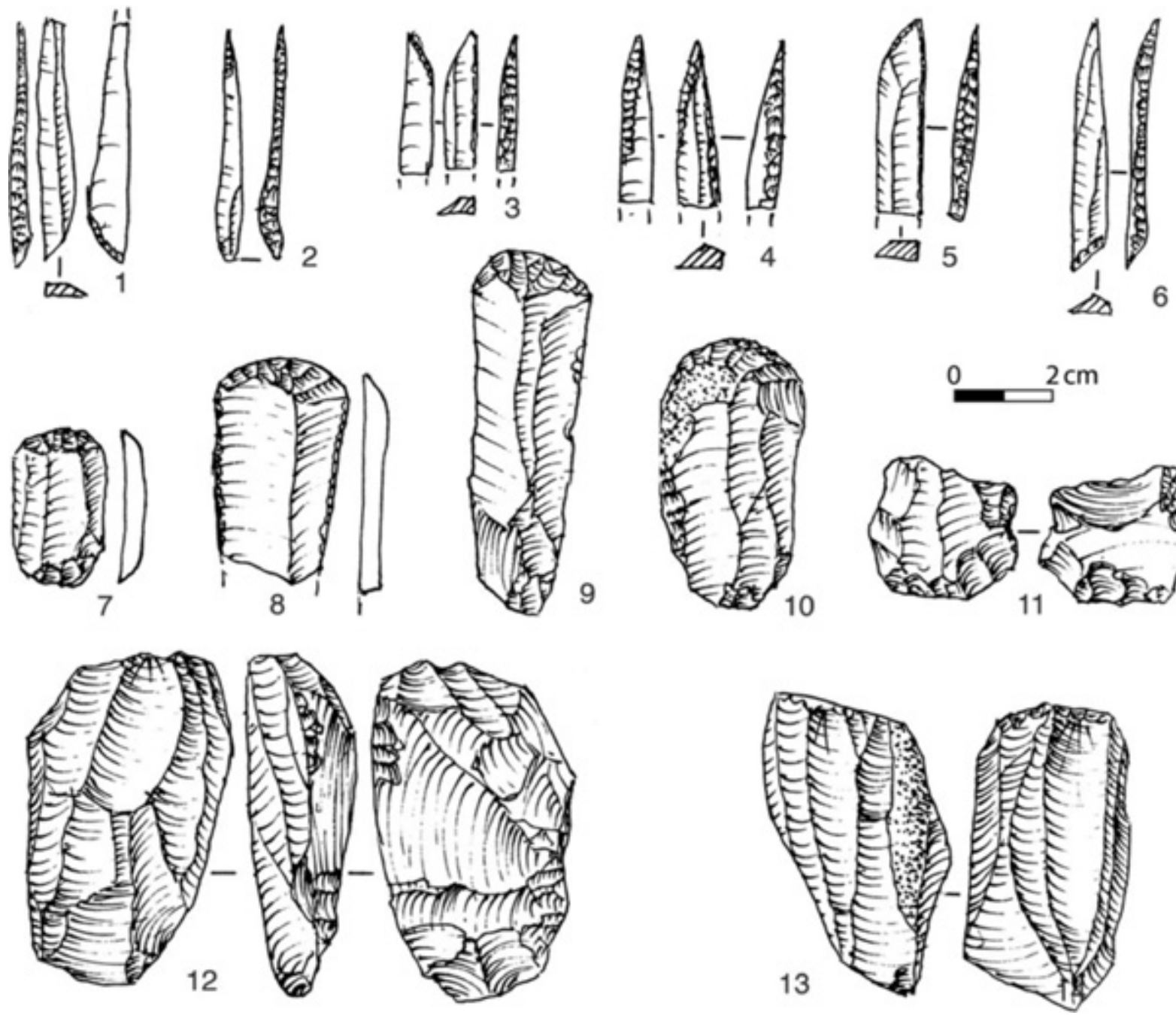

Fig. 4. Unit B: 1,2,5,6 - variants of microgravettes, with bipolar retouch; 3-4 - backed bladelets, most probably microgravette fragments; 7-10 - endscrapers; 11 - piece esquillee; 12-13 - cores (Bar-Yosef et al, 339). 